\title{
Agrarian society in transition: The adaptive potential of law
}

\author{
R.S. Taraborin* \\ Russian Presidential Academy of National Economy and Public Administration, Ekaterinburg, Russia
}

\begin{abstract}
Agrarian society is considered in terms of the functional role of law in ensuring the adaptation of individuals and social strata (estates) to the transformations that occur in its transition to an industrial (modern) state. The universal functionalism of law is described as the most important integrating factor of agrarian society in the transition era. The special importance of civil law in realization of adaptation function of law is revealed. The dualism of positive and customary law, the reasons of its formation in agrarian society and its stabilizing influence on social and class structure and its stability are analyzed. The peculiarities of civil-legal dualism in Russian agrarian society are determined. The ways of possible transformation of legal dualism in the course of system transformation of Russian society in the second part of XIX - beginning of XX centuries are analysed in details. It proves that the insoluble dual structure of Russian civil law at legislative and law-enforcement levels has created significant limitations in the implementation of the adaptive function of law in the Russian transitional era.
\end{abstract}

\section{Introduction}

The diversity of responses of various countries of the world, both at the state and collective and individual levels, to the development of the COVID-19 pandemic has been another confirmation of the urgency of a problem that has been discussed in political and academic circles for decades - the conflict between globality and locality. Against the background of a continuously increasing unification of the global economic and information space, a process of differentiation of local sociocultural worlds in this space, which tend to function relatively independently on their own and, in this sense, on traditional bases, is also continuously developing. The localization process is most evident in countries and regions that have preserved in one form or another the elements and structures of traditional agrarian civilization or agrarian society.

The duration of temporal existence and scale of spread of agrarian societies is not comparable to that of modern or industrial societies. The former are measured in millennia and virtually the entire inhabited part of the globe, with the exception of geographically and naturally isolated territories. The latter hardly exceed, even by the most optimistic estimates, two centuries and have a limited range of distribution within the "industrialised world". Therefore, it is obvious that the elements and structures of agrarian society continue

\footnotetext{
* Corresponding author: trs-2008@yandex.ru
} 
to influence directly and indirectly the everyday life and activities of individuals and collective communities, especially since agrarian economic activities retain their most important economic and socio-cultural functions even in the most highly developed countries $[1,2]$.

The experience of countries that have successfully completed the transition from an agrarian society to an industrial society has allowed us, despite the diversity of individual trajectories of this transition, to establish some system-wide regularities [3, 4]. These include the gradualness and flexibility of "incorporation" of traditional agrarian structures into the emerging new organization of society, adaptation, adaptation of agrarian methods of production and socio-cultural activity to the changed conditions of social and natural environment.

Among the tools used by the state power to reduce the inevitable social costs of the transition process (often defined in science as "modernization"), especially in the autocratic or statist model of this process, a significant place was occupied by legal means. Legislation and law enforcement, primarily judicial, ensured the creation and enforcement of rules aimed at adapting agrarian social strata (estates) to the realities of the new social class structure and the predominance of market forms of production activity. At the same time, the impossibility of using unified legal means of adaptation, sometimes even on a national scale, due to the peculiarities inherent in agrarian societies and manifested at all levels of social organization, has also come to light. Modern legal theory notes that "it often happens that different legal systems apply and compete within the same state and, conversely, non-state communities also have their own law" [5]. Therefore, only specific studies of the adaptive function of law at the country studies level can provide empirical confirmation of the theoretical ideas about the adaptive function of law in the transition processes taking place in agrarian societies.

The object of this study was the realization of adaptive potential of the most important branch of law - civil law in conditions of concrete-historical transitional process in Russian agrarian society of XVIII - early XX centuries. The purpose of the study was to determine the dependence of implementation of the adaptive function of civil law on typological features of the law formed in the traditional Russian agrarian society. The hypothesis of the study was that the lack of effectiveness of the implementation of such a function stemmed from the stability of the system of civil law dualism formed in this society.

\section{Materials and methods}

The material of the study was the documentary normative-legal base of Russian law of this period of time, presented in official publications of positive law, as well as in collections of documents on the history of Russian customary law. Application of formal-legal and comparative-legal methods of processing normative (positive and common law) material allowed to obtain the necessary data for modeling on the basis of the use of theoretical developments of domestic legal scholars of the process of implementation of adaptive function of Russian civil law.

\subsection{Theoretical foundations for the study of the adaptive function of law}

Law in this study is interpreted as a subsystem of society that has a specificity that distinguishes it from other social subsystems (economic, social, etc.).

This specificity lies in the fact that legal relations sanction or find some other form of social recognition of relations that operate in other social subsystems. In other words, the social-regulatory function of law extends to all other subsystems, which gives the legal subsystem the property of universality. "The modern Russian theory of law notes: "The 
essential, universal, transcendent criterion of law is its 'general' function of ensuring the integrity (normal functioning, reproduction) of society. This attribute is transcendent because it "goes beyond" the law itself and "is" (or is found) in society" [6].

Such transcendence of law becomes exceptionally important in times of transition. At each specific moment of the transition process, agrarian society is in a state where its various subsystems and units within them are simultaneously disintegrating, losing their former integrity, their former links integrating their properties, but also consolidating again on the basis of the formation of new elements and their interrelations, acquiring new integrity.

The "transcendent" potential of law makes it the most important integrating factor of the transition era. The political system of agrarian societies, with few exceptions, was autocratic-monarchical in nature, which in peculiar autocratic forms took place in historical Russia-Russia. Therefore, the state, represented by the monarch and the bureaucratic administrative layer, had a monopoly on legislative and law enforcement activities. Through this activity, it became possible, on the one hand, to keep the disintegration of structures and elements of all social subsystems within the limits acceptable for the system integrity, and, on the other hand, to ensure the integration of new emerging elements and structures. In order to perform this function, the law itself had to be systematized (codified) and then subjected to a permanent ongoing transformation at the normative level.

\subsection{Legal dualism as a feature of the legal system of agrarian society}

Legal dualism in this study was considered not as a dualism of public and private law (the traditional legal division going back to Roman law), but from its other side - the division of law into two components: positive law and customary law. This division practically meant the simultaneous operation of positive law - i.e. legislation established by state power - and customary law in agrarian society. The latter originally emerged and functioned at the level of primary social associations - clans and tribes.

With the development of state forms of social organisation, customary law concentrated mainly in rural communities and, to a lesser extent, in communal (as a rule, professional) urban associations. At the first stages of state formation, positive law (laws) was formed through the generalisation of the most typical forms of customary legal relations. Subsequently, state law-making itself acquired an independent importance, but before the transition (modernisation) processes in agrarian society, the legal dualism functioned as a relatively stable legal structure on the basis of different territorial and social segments.

The dual structure of law formed in this way was able to ensure relative social stability due to a peculiar division of the levels of legal regulation. On the scale of the state, positive law bound together the social strata (estates) that made up society, but at the "grassroots", local level, customary law played a similar binding role with respect to individuals and their social integration. However, it was the local, local nature of customary law that prevented its own integration beyond local communities. The latter, of course, did not mean the absence in the customary law of a particular agrarian society of norms similar in their legal meaning and causal application. The existence of such legal norms was ensured by cultural and religious traditions which united rural and urban populations even in regions of the country not directly neighbouring.

Customary law in its normative content, being defined in the categories of legal science, was predominantly civil law, as it was concentrated in the sphere of ensuring the functioning of socio-economic structural units of agrarian society. This implied that in the structure of customary law the normative-legal regulation of property (especially land), liability and inheritance relations came to the fore. As a consequence, legal dualism was formed not in the entire branch structure of the law, but exclusively in its civil law segment. 
The attitude of the state authorities towards customary law was mainly pragmatic in motivation. The existence and operation of customary law limited the state monopoly in the legal sphere, which the autocratic power could not help but aspire to by its very nature. But, firstly, the active displacement of customary law from the legal system of agrarian society was fraught with provoking deep and large-scale social conflicts. Secondly, the functioning of customary law was advantageous for the state power and the ruling nobility by the possibility to focus their efforts on organizing the system of extracting resources (in-kind and financial) from the dominated agricultural production sector in the economy, having withdrawn from the everyday regulation of agrarian and economic activities at the grassroots level.

\subsection{Civil law dualism in Russian agrarian society in transition}

The peculiarities of the civil-legal dualism in Russian agrarian society stemmed from the peculiarity of the system of "fortress", established in the era of the Moscow state, that is, the legal and informal, based on the ideology of the orthodox state, attachment of the estates to the state. This meant that all estates were entrusted with certain inherent functions which required them to perform their duties in relation to the autocratic state, the costs of which were compensated by giving them certain rights, above all in the material and material sphere (land resources).

But with regard to the bulk of the rural (peasant) population this attachment had a double content. One part of it (the so-called 'official peasantry') was directly attached to the state through settling on state land. The other part, the landowners or serfs, were attached to the State through the intermediary private owners of the land on which they lived and carried out production activities.

As a result, positive civil law in the Moscow agrarian society was the right of the nobility and a large part of the urban population, while the peasantry in their internal relations continued to be governed by the rules of customary law. The latter retained autonomy in this respect to the extent that it did not prevent the extraction of material and human resources from the agrarian sector in the interests of the state and the nobility.

The beginning of the transitional (modernization) era in the history of Russian agrarian society is usually associated in science with a set of transformations implemented in the first quarter of the 18th century in the reign of Peter the Great. Throughout this century and the first half of the next century, the transition process developed unevenly, but generally on an upward trajectory.

The systemic content of modernization in modern social science is most often understood as three main, simultaneously, but not necessarily synchronously developing processes that radically change social organization: industrialization (material and technical change), urbanization (socio-territorial and demographic change), rationalization (cultural, spiritual and political change) [7,8].

All three processes find concentrated expression in social transformation, which in general terms represented a transition from the social and class structure of social organization to the social and class structure. Law, especially legislation, was an important instrument for keeping the social transformation within relatively safe limits for the selfpreservation of the political system. The authorities needed to find the golden mean in legal policy between the systemic transformation of social relations and the preservation, in its former or slightly modified form, of an autocratic system of power based on the social and class foundation of social organisation.

The search for a "golden mean" in legal policy was embodied in the oscillation between conservatism in some legal issues and reformism in others. Legal policy was necessarily conservative where it ensured the preservation, if not all, of the "supporting" structures of 
the existing social order, and necessarily reformist where it led to the creation and maintenance of the elements and structures of the new order. The legal policy of the Russian monarchical power in the empire period needed to find a flexible compromise between tradition and innovation, between preserving the legal foundations of the former agrarian, social-social and autocratic system and introducing changes in legislation and law enforcement, which, in their entirety, ensured the evolutionary transformation of this system.

Civil law had in this case a special place in general legal policy, determined by the fact that under conditions of social transformation there were inevitable, often quite abrupt and massive, changes in the material sphere (ownership and possession of material resources, inheritance, contractual property relations, etc.). Such changes, to varying degrees but affecting all social groups (estates), belonged to those changes which covered the most socio-psychologically sensitive sphere of everyday material-property relations. That is why they were experienced most acutely and painfully by practically all groups of the country's population, and were a potential source of social tension and conflict. Seeking to maintain control over the situation in society, the state authorities could not ignore the explosive consequences of changes, especially cardinal ones, in everyday civil-legal relations.

All this dictated the need for a flexible approach to legal dualism. Modernisation objectively led to the displacement of customary law to the periphery of legal relations, with the rural population becoming the object and subject of positive law as they became involved in market economic relations and transcended the boundaries of local territorial worlds. In the long run, customary law could only retain an informal, non-institutionalised influence in the sphere of everyday psychology and domestic legal relations within the rural society itself.

During the 18th century and the first half of the 19th century, the state authorities preferred to preserve the civil-law dualism, which was favoured by the relatively slow and selective penetration of market economic relations into the rural environment. The latter was also favoured by the way of life of the rural population in Russian agrarian society, its isolated existence for generations in limited territorial and socio-cultural spaces regulated by the peasant community itself on the basis of customary law.

Evidence of the state authorities' orientation towards keeping the Russian peasant population outside the scope of positive civil law was its actual absence as an object of law enforcement in the Code of Laws of the Russian Empire of 1832. But this meant that the legal instrument of adaptation of the Russian agrarian society to changing conditions of its functioning was used by the authorities in a narrow class division - nobility and urban population.

After the beginning of the cardinal reforms by the government of Emperor Alexander II from 1861, overcoming the civil-legal dualism became increasingly imperative, without which the risk of splitting the country's population into parts living and acting in different legal spaces increased sharply. By recognising customary law as a valid law for the first time, the authorities were immediately confronted with the problem of its increasing, though not absolute, incompatibility with positive law in matters of property, ownership, contracts, etc., which created the potential for many economic and social conflicts along the conditional town-village line.

The gap in legal relations and legal consciousness which had developed along this line throughout the preceding transition process made it impossible to simply extend the norms of existing civil law to the peasantry. In other words, it was impossible to eliminate the civil-law dualism by abolishing one of its components. This would have served not to adapt rural, traditional agrarian Russia to the realities of the coming industrial age, but to repel it, to contrast the village with the city, with a very possible prospect of intra-Russian civil conflict. 
Another way, capable of avoiding the extreme forms of conflict, albeit over a long period of time, and indeed of adapting the legal consciousness of the peasantry to the norms of positive law, could be the formation of various intermediate forms of civil legislation and the means of its enforcement, which would find a place for the norms of customary law compatible with the positive law in force. In the second half of the 19th century, this way found practical application, first, in the attempt of the state authorities to develop a new allRussian civil legislation in the form of the Civil Code, and second, in the creation of an intermediate judicial institution - the volost court procedure, which applied the customary law norms.

However, the proposals made by professional lawyers during the drafting of the Civil Code to partially incorporate the most common rules of customary law, which would have allowed the peasantry to be partially included in the system of positive civil law, were almost never implemented. In addition, due to a number of extralegal circumstances, the draft remained a draft and was not implemented in law. The activities of parish justice had some merit, partly adapting the peasant population to judicial resolution of disputes, but its scope was limited. The most active and enterprising part of the peasantry, not finding it possible to resolve issues of interest to them at this level, preferred to move, especially in the first decades of the twentieth century, into the sphere of positive civil procedure law [9]. It was this spontaneous movement, directed not by the authorities, but by the direct economic interests of the peasantry, which was changing over to a market economy, that turned out to be the most effective means of its legal adaptation, but it did not manage to acquire a truly mass character.

On the whole, therefore, the civic-legal dualism which had almost lost its positive regulating qualities with the deepening of modernization transformations in the early twentieth century remained unsolved, and this played its negative role in the mass spread of archaic ideas about law and justice among the peasant masses in the conditions of the revolutionary upheavals of 1917 and the following years.

\section{Results and discussion}

The research carried out has yielded the following results.

To establish the functional role of law as a means of adaptation of individuals and collective communities of agrarian society to the transition process, implementing the systemic transformation in the direction of modern society.

To determine the origin, nature and functionality of legal dualism and civil-legal dualism as means to ensure relative social stability of agrarian society.

To reveal the peculiarities of the civil-legal dualism in the traditional agrarian Russian society and the main trends of its transformation in the conditions of the transition era.

To determine the ways of using the civil-legal dualism as one of the legal instruments of adaptation of agrarian segment of Russian population to the deepening of society modernization changes in the second half of the XIX - beginning of the XX centuries.

To obtain a representative substantiation of the hypothesis regarding sustainability of legal dualism as a factor that significantly influenced the lack of implementation of the adaptive potential of law in the context of transitional processes in the agrarian society.

The results of the study have created a field for discussion of the following scientific problem, which is fundamentally important and requires a comprehensive and not only legal analysis: legal dualism, being a fairly common phenomenon inherent in the legal systems of agrarian societies, to what extent and in what forms has affected the actual economic activity, and in particular, whether its sustainability, including in Russia, can be explained in terms of determining the impact of natural and climatic factors on the functioning of the agrarian sector 
In this way, one of the possible directions for future comparative research is outlined, the object of which could be the systems of legal and civil dualism in typologically similar types of agrarian societies to pre-revolutionary Russia.

\section{Conclusions}

The study of agrarian civilizations of antiquity and agrarian societies of medieval and modern times from the historical and legal perspective is an important resource for the development of interdisciplinary research, characteristic of the modern stage of social science evolution. The importance of such research is determined by the fact that, being considered from different disciplinary positions, agrarian society loses the unidimensionality inherent in its study from only one disciplinary perspective. In the interdisciplinary field it appears as a dynamic system, which has existed in various forms and which in turn has had a prolonged impact on the diversity of paths of transition to modern society and the diversity of current functioning forms of this society.

\section{References}

1. A. Dirlik, R. Prazniak, A. Woodside, Global capitalism and the future of agrarian society, 1-323 (2015) doi: 10.4324/9781315634463

2. T. Kim, A. Heshmati, J. Park, Technological Forecasting and Social Change, 77(3), 479-499 (2010) doi: 10.1016/j.techfore. 2009.08.005

3. S.N. Eisenstadt, Comparative Civilizations and Multiple Modernities, 1055 (Leiden, Brill. XI, 2003)

4. D. Sachsenmaier, J. Riedel, S. Eisenstadt, Reflections on Multiple Modernities, European, Chinese and Other Interpretations, 314 (Leiden, Brill. X, 2002)

5. J.-L. Bergel, General Theory of Law, 244 (Moscow: NOTA BENE, 2000)

6. I.L. Chestnov, Post-classical theory of law, 316 (Saint Petersburg, Publishing house "Aleph-Press", 2012)

7. H. Joas, W. Knöbl, Social theory. Twenty Introductory Lectures, 442-487 (Saint Petersburg, Aletheia, 2011)

8. From agrarian society to the welfare state, Modernisation of Western Europe from the 15 th century to the 1980s, 432 (Moscow, ROSSPAN, 1998)

9. J. Burbank, Russian Peasants Go to Court. Legal Culture in the Countryside, 19051917, 374 (Bloomington: Indiana University Press. XXI, 2004) 